\title{
Marketing mix and factors that affect cigarette consumption
}

\author{
Tommy Hardiyono $^{1 *}$, Bambang Siswadi ${ }^{1}$, Masyhuri Machfudz ${ }^{1}$ \\ Department of Agribusiness, Faculty of Agriculture, University of Islam Malang, Indonesia \\ *E-mail: tommyhardiyono@gmail.com
}

\begin{abstract}
The Ministry of Industry noted the number of workers in the industrial sector was 5.98 million people, higher than the number of manufacturing and distribution (4.28 million), and the rest belonged (1.7 million). The purpose of this study is to analyze the marketing mix and the factors that influence the consumption of cigarettes. The research data consisted of primary data obtained through direct interviews with consumers, taken by accident sampling with a total sample of 95 respondents. Data analysis uses multiple linear regression models. The results showed that the product in the form of product availability contributed to cigarette consumption by $50.52 \%$, the price in the form of a price ratio of $45.26 \%$, the distribution variable in the form of ease in getting products by $47.36 \%$, and promotion in the form of advertising attractiveness by $46,31 \%$. Price, distribution, and promotion have a significant effect on cigarette consumption, while products do not affect. It is necessary to improve the quality of packaging, physical form, and taste with a balanced price.
\end{abstract}

Keywords: marketing mix, product, price, distribution, promotion

\section{INTRODUCTION}

The cigarette industry is one of the agro-industries made from tobacco (Suprihanti et al., 2019). The cigarette industry is also labor-intensive and contributes considerably to the nation's economy because cigarette production does not only use machines but also manually using human skills that can absorb a large enough workforce. Khairiyah et al. (2019) and Wijaya (2019) said that marketing strategy plays a critical role in a company's marketing planning, by providing specific information about its current market position and opportunities to achieve the market position in the future. As a marketer, understanding consumer behavior is fundamental because knowledge of consumer behavior is the basis for implementing marketing strategies. Based on the 2016 National Socio-Economic Household Survey data that the share of expenditure on cigarettes is quite large even number three after cereals and processed food. Cigarette expenditure share based on expenditure quintiles in 2016 in order from quintile $1(\mathrm{Q} 1$ = poorest $)$ to quintile $5(\mathrm{Q} 5=$ richest $)$ amounted to $12.94 \%, 15.16 \%, 16.11 \%, 15.12 \%$, and $11.60 \%$. From the results of this study, it can be seen that as income increases only in quintile 3 , households increase cigarette consumption, but in quintiles 4 and 5, the share of cigarette expenditure decreases. It can be concluded that groups of rich (not poor) households reduce cigarette consumption (Khoiriyah et al., 2020).

Francisca (2003) concludes that marketing mix factors have an influence on consumers successively are price, product, and distribution. Then M. Nasir (2010) said that there was a significant relationship between consumer attributes, which included age, education level, and taste in the decision to purchase Gudang Garam cigarettes. From the results of this research, it can be seen that there is one thing that is not explained in his research that is the promotional attributes that have an influence on consumer decisions in buying or consuming products as described in the research of Ardy Dharmawan Salim (2013), namely marketing communication strategies of cigarette companies often used by young people as their target market, as evidenced by promotions, advertisements and sponsorships that use styles, icons and all imagery about youth. Not only that, music shows, sports schools, etc. This is also one form of support for Ellen Madhalena's research (2016), which 
simultaneously shows that event marketing has a significant effect on the Djarum Super Mild cigarette brand image. While partially shows that event marketing variables with involvement dimensions do not significantly influence brand image, the interaction does not significantly influence the brand image. Intensity significantly influences the brand image. Individuality, innovation, and integrity do not have a significant effect on brand image. This also continues in the study of Fazza Ilham Fachriza (2017) Sampoerna A Mild cigarettes have power in the marketing mix in sub-variable places. That way, it can be seen that consumers can easily access Sampoerna A Mild cigarettes. Sampoerna A Mild cigarettes have a weakness in prices where consumers cannot reach the price of Sampoerna A Mild cigarettes because government regulations already regulate the price of cigarettes itself. Consumers are more affected in deciding to buy because Sampoerna cigarettes are known for their quality and easy access to purchases.

Research on the marketing mix and the factors that influence it has often been done both inside and outside the country, among others by Andrews \& Franke (1996), Mwangi (2002), Cruz, et al. , Chauhan, H., \& Setia, P. (2016), Purwana, AJ (2019), Soule et al. (2019), Barrington-Trimis, JL (2020), Kumar, P., \& Subhasini, J. (2020). In general, it can be concluded from all the above studies that the marketing mix affects the purchase of cigarettes. Therefore, this study also wants to analyze two problems related to consumer behavior, namely identifying the marketing mix factors and analyzing the factors that influence consumers in consuming cigarettes. The study was conducted in Dinoyo Village, Lowokwaru District, Malang City. Research data in the form of primary data collected through direct interviews with consumers as many as 95 respondents. Determination of the sample by accidental random sampling. Data analysis of data uses multiple linear regression models. The marketing mix analysis will obtain the percentage of information on each marketing mix factor on cigarette consumption. Through the regression analysis, results can be obtained information on the influence of four factors, namely product, promotion, distribution, and price on cigarette consumption. Marketers can use the results of the research as a material consideration in operational activities related to marketing strategies and face competition in the cigarette industry.

\section{METHODS}

This research was conducted in November-December 2019 in Dinoyo Village, Lowokwaru District, Malang City. Accidental sampling was taken as many as 95 people with the consideration that the number of variables of 5 types was multiplied by the number of variables observed as many as 18 , to obtain a total sample of 95 respondents (Malhotra, 1993).

This study uses a model of multiple linear regression equations approach. According to Sugiyono (2014) that "Multiple linear regression analysis intends to predict how the state (ups and downs) of the dependent variable (criterion), if two or more independent variables as a predictor factor are manipulated (raised the value down). The formula is: $Y=\alpha 0+\alpha 1 \times 1+\alpha 2 \times 2+\alpha 3 \times 3+\alpha 4 \times 4$ with the statement $\mathrm{Y}=$ cigarette consumption, $\alpha 0=$ constant, $\mathrm{x} 1=$ Product variable, $\mathrm{x} 2=$ Price Variable, $\mathrm{x} 3$ $=$ Distribution Variable, and $\mathrm{x} 4=$ promotion variable. Here are some stages of multiple linear regression tests, namely

\subsection{Testing of determination coefficient}

This determination coefficient test $\left(\mathrm{R}^{2}\right)$ can be used to predict how much influence the independent variable $(\mathrm{X})$ has on the independent variable $(\mathrm{Y})$. with the condition that the $\mathrm{F}$ test results are significant:

$$
\begin{aligned}
& \text { N } \\
& \Sigma \\
& R^{2}=\frac{1\left(\mathrm{Y}_{i}-Y\right)^{2}}{n}
\end{aligned}
$$

Information:

$\mathrm{R}^{2}=$ coefficient of determination

$\mathrm{k}=$ number of independent variables

$\mathrm{n}=$ number of data members or cases 


\subsection{Simultan testing $\left(\mathrm{F}_{\text {test }}\right)$}

The F test in this study was used to test the significance of the dependent variable (product, price, distribution, and promotion) on the independent variable (Consumption) simultaneously. According to Sugiyono (2014) is formulated as follows

Information:

$\mathrm{K}=$ Number of variables

$\mathrm{n}=$ Number of samples

$F=\frac{R^{2} /(k-1)}{\left.1-R^{2} / n-k\right)}$

\subsection{Parsial testing $\left(\mathrm{t}_{\text {test }}\right)$}

This test is conducted to determine the significance of the partial role between the independent variables on the dependent variable. It assumes that other independent variables are considered constant. According to Sugiyono (2014), using the formula:

$t=r \frac{\sqrt{n-2}}{\sqrt{1-r^{2}}}$

Information:

$\mathrm{t}=$ distribution $\mathrm{t}$

$\mathrm{r}=$ partial correlation coefficient

$\mathrm{R}^{2}=$ coefficient of determination

$\mathrm{n}=$ the number of samples

So that the results of the linear regression analysis can be interpreted, it must meet the requirements of the absence of multicollinearity. Multicollinearity test is useful for detecting the presence or absence of multicollinearity. It can be seen from the amount of VIF (Variance Inflation Factor) and Tolerance. Guidelines for a multicollinearity-free regression model is to have a tolerance figure close to 1 . VIF limit is ten if the VIF value is below 10 , then there is no multicollinearity (Gujarati, 2012)

\section{RESULTS AND DISCUSSION}

\subsection{Characteristics of respondents}

In Dinoyo Subdistrict, Lowokwaru District, Malang City consists of 7 (seven) Community Associations $(\mathrm{RW}=$ local term). Each RW was given 12-13 questionnaires. The results of a simple statistical analysis obtained the distribution of respondents' identities based on age presented in Table 1. This information can be taken into consideration and supporting the analysis of the cigarette and processing industry. Table 1 shows the distribution of respondents by age group.

Table 1. Distribution of respondents by age group.

\begin{tabular}{ccc}
\hline $\begin{array}{c}\text { Age groups } \\
\text { (years) }\end{array}$ & $\begin{array}{c}\text { Total } \\
\text { (people) }\end{array}$ & $\begin{array}{c}\text { Percentage } \\
(\%)\end{array}$ \\
\hline $15-20$ & 63 & 66.3 \\
$21-25$ & 20 & 21.0 \\
$26-40$ & 7 & 7.3 \\
$41-60$ & 3 & 3.1 \\
$>60$ & 2 & 2.1 \\
\hline Total & 95 & 100 \\
\hline
\end{tabular}

Source: Author's computation, 2020.

Based on the gender of the respondent, information was obtained that from 95 consumer samples obtained 93 men (98\%) and two women (2\%). Smokers are predominantly male and quite alarming, female smokers are still found, although only $2 \%$. When viewed from the age distribution, it can be described that the age group that consumes the most cigarettes is the 15-20 years age group, i.e., 63 respondents $(66.3 \%)$ followed by $21-25$ years of age by 20 respondents $(21.0 \%)$, then aged 2640 years $(7.3 \%)$, and subsequently in the 41-60 year age group 3 people $(3.1 \%)$ while the old age 
group is aged 60 and over as many as two people (2.1\%). It can be concluded that smokers in Dinoyo are dominated by middle and high school children, where these children range in age from 15-20 years.

When viewed from the type of cigarettes consumed, the dominance of cigarettes consumed by the Dinoyo community is Gudang Garam, with 47 people (49\%), followed by 18 Sampoerna cigarettes (19\%), Marlboro with 17 people (18\%). Those not consumed by Dinoyo people are Murni and Djarum, which is only $7 \%$ and $6 \%$. The distribution of respondents by the brand of cigarettes consumed can be seen in Table 2 .

Table 2. Distribution of respondents by the brand of cigarettes consumed.

\begin{tabular}{lcc}
\hline Cigarette brands & Total (people) & $\begin{array}{c}\text { Percentage } \\
(\%)\end{array}$ \\
\hline Sampoerna & & 18.9 \\
Gudang Garam & 18 & 49.4 \\
Djarum & 47 & 6.3 \\
Marlboro & 6 & 17.8 \\
Murni & 17 & 7.3 \\
\hline Total & 7 & 100 \\
\hline
\end{tabular}

Source: Author's computation, 2020.

\subsection{Marketing mix}

It can be seen that from the product variable, namely, product availability is a factor or reason for consumers to consume cigarettes with the parameters of strongly agree $50.52 \%$. This is in line with research by Charles Victor B. Saragih (2013), namely as a product and customer stability. Then the price variable that is the comparison is a factor or reason for consumers to consume cigarettes with agreed parameters of $45.26 \%$. This also supports and is conveyed in the research of Inka Nuromavita (2016) that the price comparison perceived by consumers should be controlled at an affordable price and does not change with a short time and then the distribution variable, namely the ease of obtaining the product is a factor or reason for consumers in consuming the cigarettes with agreed parameters of 47.36\%. This also supports and is conveyed in the research of Marisa Arnindita Palma (2016), which states that there is no difficulty in obtaining the product. The promotion variable in the form of ad appeal is a factor or reason for consumers to consume cigarettes with agreed parameters of $46.31 \%$. This also supports and is conveyed in the research of Septa Adi Sasetyo (2012), which is an image builder of products and companies as a level of attractiveness to customers to buy these products.

\section{Product}

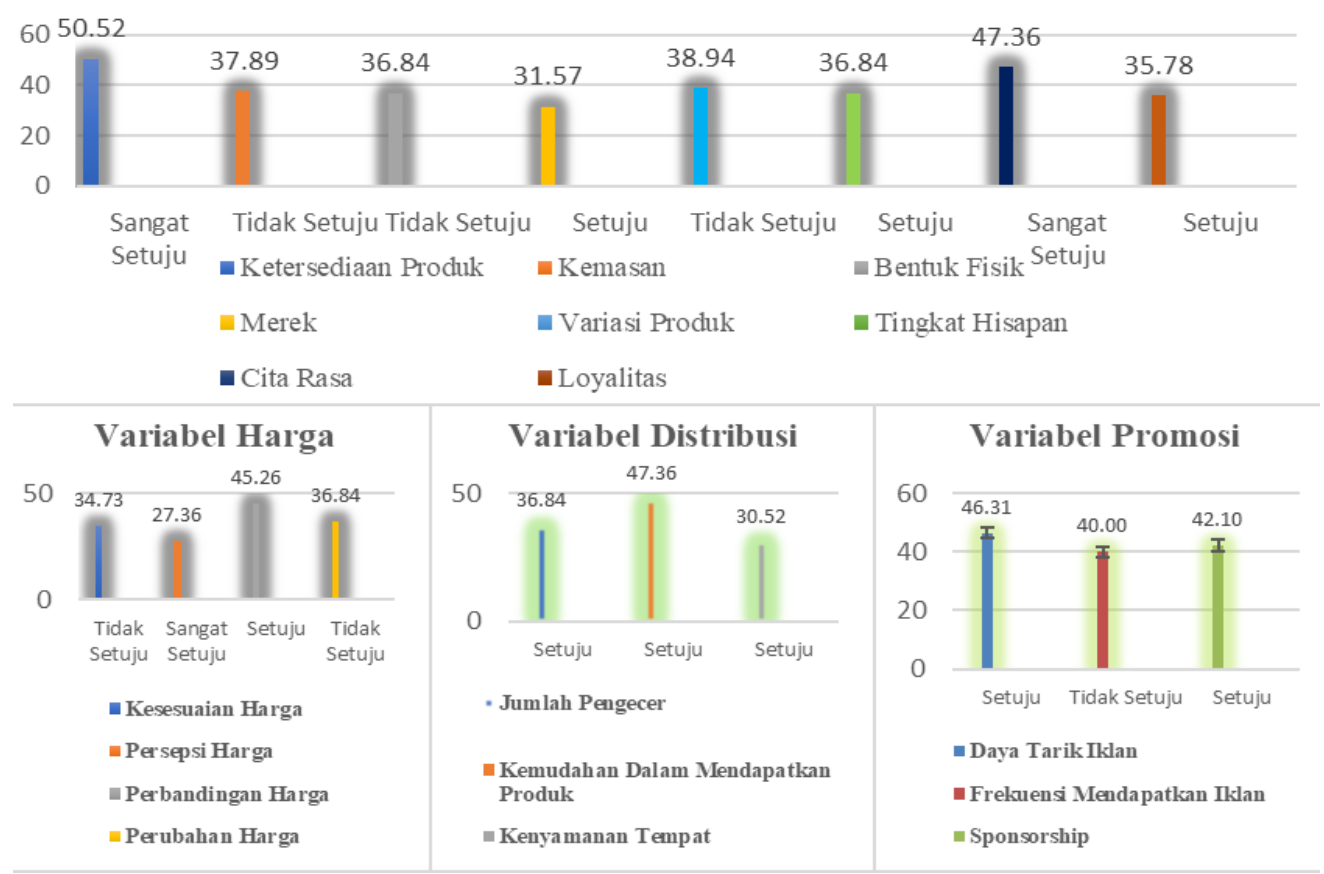




\subsection{Factors that influence consumers in consuming cigarettes.}

In consuming a product, consumers are influenced by several factors, including price, taste, income, age, packaging, promotion, location of sales, and others. In this study, the four variables analyzed related to the consumption of cigarettes by the Dinoyo, and the people were the product, price, distribution, and promotion. The results of the regression analysis of the factors that influence consumers in consuming cigarettes can be seen in Table 3.

Table 3. The regression analysis of factors that influence consumers in consuming cigarettes.

\begin{tabular}{|c|c|c|c|c|c|}
\hline Variable & Coefficient & SE coeff & $\mathrm{t}$ & $\mathrm{P}$ & VIF \\
\hline (Constant) & 140.82 & 12.46 & 11.31 & 0 & \\
\hline Product $\left(\mathrm{x}_{1}\right)$ & 1.573 & 2.408 & 0.65 & 0.515 & 1.137 \\
\hline Price $\left(\mathrm{x}_{2}\right)$ & -5.187 & 1.982 & -2.62 & 0.010 & 1.074 \\
\hline Distribution $\left(\mathrm{x}_{3}\right)$ & 22.381 & 2.103 & 10.64 & 0.001 & 1.272 \\
\hline Promotion $\left(\mathrm{x}_{4}\right)$ & 7.060 & 2.22 & 3.18 & 0.002 & 1.155 \\
\hline $\mathrm{S}=13.6274$ & $\mathrm{R}^{2}=69 \%$ & $\mathrm{R}^{2}(\operatorname{adj})=67.7 \%$ & & & \\
\hline $\mathrm{F}_{\text {(test) }}: 50.17$ & & Prob $F_{\text {(test) }}: 0.000$ & & & \\
\hline
\end{tabular}

Source: Author's computation, 2020.

The results of data analysis obtained the consumption equation $(\mathrm{Y})$ of the marketing mix in cigarettes can be written as follows:

$\mathrm{Y}=141+1.57$ products -5.19 price +22.4 distribution +7.06 promotion .

The coefficient of determination is obtained $\mathrm{R}^{2}$ of $69 \%$, which means that the marketing mix model for cigarette consumption is $69 \%$, the remaining $31 \%$ is explained by other variables outside the model, including taste and income. Multicollinearity test shows that there is a disturbance of classical assumptions in an OLS (Ordinary Least Square) multiple regression model that is free from a close relationship between independent variables or multicollinearity. Based on the VIF (Variance Inflation Factor), the results of the analysis show a figure below 10. Therefore, the multiple linear regression equation models of the factors that influence cigarette consumption can be interpreted.

\subsubsection{Test the model.}

For the simultaneous $\mathrm{F}$ value of 50.17 and have a significant effect on the significant level $=0.0001$ (99\%). This shows that the multiple regression model can be used to estimate the independent variables (product, price, promotion, and promotion) to the dependent variable (cigarette consumption). It means all variables simultaneously influencing the dependent variable (cigarette consumption).

\subsubsection{Partial test.}

After the model is significant, it means that together with four variables affect cigarette consumption, and a partial test is then performed. A partial test is a test to see the effect of each independent variable influencing the dependent variable. The following is an explanation of each variable that affects consumers in consuming cigarettes.

\section{Product}

T-test results indicate that the product variable does not affect cigarette consumption, with a probability number $(\mathrm{P})$ of 0.515 . Based on field observations show that of the 8 product attributes, it can be explained that a positive response in the direction of a product's availability is the brand, the level of suction, taste, and loyalty. This is because none other than the respondents are consumers who know very well how to enjoy a cigarette on the taste and level of suction. This can be seen through the brand as a sign. This is what triggers a loyalty and desired product availability. Contrary to the packaging, physical form and variety of products due to the reality in the field, to judge a product that is the taste of the cigarette, if the taste has given a "feel" to the consumer, then it does not matter how the variation and physical form. 
2. Price

The price variable is very influential on cigarette consumption with a probability number $(\mathrm{P})$ of 0.010. The price variable regression coefficient is negative. This can be interpreted that rising prices reduce cigarette consumption. This is consistent with the economic theory that if prices rise, then demand falls.

The results of the tabulation of data in the field inform that there is a price match, price perception, price comparison and price changes in the agreement level is in the perception and price comparison. The perception here is merely a view on a product and a more specific comparison to compare all products in detail. Besides, consumers pay close attention to the quality of products at prices offered to match their needs and expenses. Overall the price variable is one of the parts considered by Dinoyo people in buying cigarettes and consuming the product.

3. Distribution

The distribution variable is very influential in cigarette consumption with a probability number (P) of 0.001. The number of positive regression coefficients gives the meaning that if the distribution increases in quality and speed, cigarette consumption also increases. This distribution is very related to product variables. Referring to the results of product research, if the Dinoyo community wants the availability of products, automatically, the role of the distributor is needed so that the need to buy and consume cigarettes is readily available everywhere and anytime.

4. Promotion

The promotion variable is also very influential on cigarette consumption, with a probability number $(\mathrm{P})$ of 0.002 . The promotion coefficient number is also positive, which means that if the promotion increases, the Dinoyo community also increases cigarette consumption. Promotion is essential for companies and distributors as a form of marketing. It aims to provide consumer attraction. Promotion is also achieved through the provision of sponsorship services because it is a form of expansion of the company's introduction and contribution to its products. Besides that, the promotion also benefits the community. However, field information shows that the frequency (capture power) of getting advertisements is not a factor in Dinoyo's interest in consuming cigarettes. What the Dinoyo community needs is the quality of the product, not how much and how often consumers receive the ad.

\section{CONCLUSION}

Based on the results of research on the marketing mix of cigarette products in Dinoyo Subdistrict, Lowokwaru District, Malang, it can be concluded that the factors of the marketing mix are together identified, namely the product variable in the form of product availability with a percentage of $50.52 \%$, the price variable is in the form of price comparison with percentage of $45.26 \%$, the distribution variable in the form of ease in getting products with a percentage of $47.36 \%$ and the promotion variable in the form of advertising attractiveness with a percentage of $46.31 \%$. Price, distribution, and promotion variables have a significant effect $(99 \%$ or $\mathrm{p}=0,0001)$ on cigarette consumption. In contrast, product variables do not affect cigarette consumption.

Referring to the results of the study can be given several suggestions to improve the quality and quantity of the marketing mix, among others: the need to improve the quality of packaging, physical form, and taste with a balanced price provided by distributors or retailers. This needs to be done so that consumers can maintain the sustainability of a product or increase customer loyalty. The next suggestion is to improve services and services in terms of marketing and promotion to consumers or recipient sponsors so that consumers can trust the company's existence and image.

\section{REFERENCES}

Andrews, R. L., \& Franke, G. R. (1996). Dynamics of aggregate response sensitivities to marketing mix variables. Journal of Business Research, 36(2), 145-155.

Aqsa Dwi Cahyo. 2013. Pengaruh Atribut Produk Terhadap Keputusan Pembelian (Survei Pada Konsumen Rokok Gudang Garam Internastional. Banyuwangi.

Charles Victor B. Saragih 2013. Pengaruh Kualitas Produk, Ketersediaan Produk Dan Gaya Hidup Terhadap Keputusan Pembelian Produk Lulur Mandi Sumber Ayu Di Jakarta. 
Barrington-Trimis, J. L. (2020). Reducing the Adverse Public Health Impact of Menthol Cigarettes in Disparate Populations.

Chauhan, H., \& Setia, P. (2016). Discouraging cigarette smoking through de-marketing strategies. Future Business Journal, 2(1), 31-39.

Cruz, T. B., Wright, L. T., \& Crawford, G. (2010). The menthol marketing mix: targeted promotions for focus communities in the United States. Nicotine \& Tobacco Research, 12(suppl_2), S147S153.

Ellen Madhalena. 2016. Pengaruh Event Marketing Terhadap Brand Image Rokok Djarum Super Mild Pt Djarum. Universitas Telkom.

Fazza Ilham Fachriza. 2017. Pengaruh Bauran Pemasaran Terhadap Keputusan Pembelian Rokok Mild. Universitas Telkom.

Fransisca. 2003. Analisis Preferensi Konsumen Berdasarkan Bauran Pemasaran Rokok Djagung Padi Hijau. Universitas Brawijaya. Malang.

Inka Nuromavita. 2016. Pengaruh Ketidakpuasan Konsumen, Cita Rasa, Merek dan Persepsi Harga Terhadap Perpindahan Merek Sepeda Motor Yamaha Ke Honda. Semarang.

Jilly Bernadette Mandey. 2013. Promosi, Distribusi, Harga Pengaruhnya Terhadap Keputusan Pembelian Rokok Surya Promild. Manado.

Khairiyah, R., Wibowo, R., \& Januar, J. (2019). Dinamika Agribisnis Tembakau Dalam Perekonomian Provinsi Jawa Timur. UNEJ e-Proceeding.

Kotler, P. 2002. Manajemen Pemasaran. Edisi Milenium. Prenhallindo. Jakarta.

Kumar, P., \& Subhasini, J. (2020). Effectiveness of Marketing Strategy Formulation in Biomedical Healthcare Industry. International Journal of Research in Pharmaceutical Sciences, 11(1), 466470.

M. Nasir. 2010. Pola Pengambilan Keputusan Konsumen Rokok. Universitas Muhammadiyah Surakarta. Surakarta.

Malhotra, Naresh K. 1993. Marketing Research: An Applied Orientation. Partice Hall International Inc. New York.

Marisa Arnindita Palma. 2016. Pengaruh Kualitas Produk, Kemudahan, Dan Harga Terhadap Niat Beli Ulang Dengan Kepuasan Sebagai Variabel Intervening. Surabaya.

Mwangi, J. K. (2002). Effects of the tobacco regulation on the marketing mix of tobacco firms in Kenya (Doctoral dissertation).

Nikmatul, K., Ratya, A., Nuhfil, H., \& Wahib, M. A. (2020). The analysis demand for animal source food in Indonesia: using Quadratic Almost Ideal Demand System. Business: Theory and Practice, 21(1), 427-439.

Purwana, A. J. (2019). CIGAR MARKETING MIX STRATEGY IN DEVELOPING COUNTRIES: DOES BRAND IMAGE INFLUENCE THE PURCHASING DECISION PROCESS?. European Journal of Management and Marketing Studies.

Saragih, Ria Desrina. 2013. Menentukan Model Persamaan Regresi Linier Berganda dengan Metode Backward pada Kasus Penyalahgunaan Narkoba di Tanah Karo. Skripsi USU. Medan.

Septa Adi Sasetyo. 2012. Pengaruh Daya Tarik Iklan terhadap pembentukan citra Merek Pepsodent. Bandung.

Soule, E. K., Sakuma, K. L. K., Palafox, S., Pokhrel, P., Herzog, T. A., Thompson, N., \& Fagan, P. (2019). Content analysis of internet marketing strategies used to promote flavored electronic cigarettes. Addictive behaviors, 91, 128-135.

Sugiarto, Dergibson Siagian, Lasmono Tri Sunaryanto dan Deny S. Oetomo. 2003. Teknik Sampling. PT Gramedia Pustaka Utama. Jakarta.

Suprihanti, A., Sinaga, B. M., \& Kustiari, R. (2019). Dampak Kebijakan Cukai Rokok terhadap Pasar Input serta Kesejahteraan Petani Tembakau dan Cengkeh di Indonesia. Jurnal Agro Ekonomi, 37(1), 1-23

Tim Riset CNBC. 2018. (Consumer News and Business Channel) Indonesia.

Badan Pusat Statistik (Statistics of Malang Municipality). 2020. Kota Malang.

Rekapitulasi Data Monografi.2014. Keadaan Pada Bulan Januari s/d Juni. 2014. Kota Malang.

Wijaya, D. T. (2019). Analisa pengaruh content marketing terhadap customer retention dengan brand experience dan customer engagement sebagai variabel intervening pada konsumen rokok sampoerna di surabaya. Jurnal Strategi Pemasaran, 6(2), 9. 